\title{
Analysis Evacuation Route for KM Zahro Express on Fire Condition using Agent - Based Modeling and Fire Dynamics Simulator
}

\author{
Trika Pitana ${ }^{1}$, Muhammad Badrus Zaman ${ }^{2}$, Dioco Carlos Kristian Perdana ${ }^{3}$, Aleik Nurwahyudi ${ }^{4}$
}

\begin{abstract}
- safety is the thing that needs to be preferred by users of transport, passengers should also understand about safety procedures and evacuation procedures in the means of transport. There have been many accidents that happen in the world of transport, particularly in the shipping world, from 2010 to 2016 is no more than 50 accidents of ships in accordance with the cause recorded by KNKT (Komisi Nasional Keselamatan Transportasi). On this research was discussed the evacuation time on the ship KM Zahro express that occurred earlier in the year 2017 in the Kepulauan Seribu, DKI Jakerta. Almost all passenger dead caused by fire from power source in engine room. This research explain about evacuation time and dangers from fire that interfere the process of evacuation. The methods used are Agent Based Modeling and Simulation (ABMS) and Fire Dynamics Simulator (FDS) for modeling fire simulation as well as using basic rules which refer to the International Maritime Organization (IMO). Result of Evacuation simulation calculation on normal conditions that match at actually condition is 29,783 minutes, showing the evacuation time is not below the performance standard.
\end{abstract}

Keywords — agent based modeling, evacuation, fire accident, fire dynamic simulator.

\section{INTRODUCTION}

$\mathrm{E}$ vacuation is a very important matter in a ship accident. Due to ship accident, evacuation is considered important to protect the crew and passengers in a ship. Things need to be done prior to prevent any casualties in a fire accident, is to make efficient evacuation route. Considered efficient when the evacuation processed in short amount of time, as to avoid any casualties in the accident. Data showed that $35 \%$ accident in a ship caused by fire. Causes of fire accident should be notice, like material used, workspace temperature and ventilation in engine room. It is important to note which area that will cause worst impact when fire occur, so while planning the evacuation route, it can avoid those area. Because, it can harm the passengers while processing evacuation.

The important thing in the evacuation is the simple evacuation route and the route signs, so the passenger can understand easily the evacuation routes. Otherwise, there are other factors that must be considered, such as passenger's characteristics, age, gender, and weight. It has an impact on the passenger walking speed that matter on the evacuation process. And other things to know is awareness time, the time when passengers can recognize the danger. Based on International Maritime Organization (IMO) calculation, length of corridors, doors and stairs own its safety factors related to crew's

Trika Pitana, Departement of Marine Engineering, Institute Technology Sepuluh Nopember, Surabaya 60111, Indonesia. E-mail: trika@its.ac.id

Muhammad Badrus Zaman, Departement of Marine Engineering, Institute Technology Sepuluh Nopember, Surabaya 60111, Indonesia. E-mail: druz zaman@its.ac.id

Dioco Carlos Kristian Perdana, Departement of Marine Engineering, Institute Technology Sepuluh Nopember, Surabaya 60111, Indonesia. E-mail: dioco13@ne.mhs.its.ac.id

Aleik Nurwahyudi, Komite Nasional Keselamatan Transportasi Indonesia, E-mail: aleiknurwahyudi@gmail.com speed of walking. Relation between the characteristics of the crew and the condition in a ship will affect in a pattern of evacuation. [1]

The characteristics of the passenger and ship in fire conditions can affect the crew in the process of evacuation. Agent-Based Modeling and Simulation (ABMS) can provide models to the level of each individual behavior, as well as the adaptation process that allows any changes the nature of each individual can assist in modeling system, so the model will be similar to reality. [3][4]

This research basically investigate on the causes of the unsuccess of pasenger evacuation on KM Zahro Express. The discussion relation to methodology for solving the case, the passenger evacuation and fire accident are describe in this study.

\section{METHODOLOGY}

This study based on methodology flow chart that has been determined (as shown in figure 1). Several data about the ship and it accident are needed to start analysis. The required data are main principal data, manifest data, general arrangement, engine room layout and evacuation route. Then, data are analyzed based on SOLAS (Safety of Life at Sea) and IMO (International Maritime Organization).

This study also uses the support simulator such as ABMS (Agent-Base Modeling and Simulation) with Pathfinder and FDS (Fire Dynamics Simulator) using Pyrosim. After getting the result form simulation in pathfinder, it is rquired to calculate the evacuation time with standard performance simulation that require in IMO. It aims to get the real evacuation time with the exact amount of passenger and the exit doors that used while the accident..

\section{A. ABMS (Agent Based Modeling and Simulation)}

The Agent-Based Modeling and Simulator (ABMS) is designed to model a place that has a seat, path, exit 
door, humans, and others. This allows to model a lot of humans and fire on one place. The purpose of this system is to simulate the evacuation of such a large crowd on the building, auditorium, stadium or concert hall. The system must able to show how agents interact each other in an emergency state, the fire situation, as well as space management can interfere the evacuation process, as well as agents who must avoid the fire as much as possible. The fire also represented as an agent who created and produced smoke. This system is used to plan and prepare an emergency case and offers the advantage of the evacuation process in the field, to minimalize the victims (shown in figure 2).[3][18]

An ability to describe the environment with chairs, street, exit, and the position of the agent. [7]

- The ability to create adjustable multiple deployment process with fire and smoke production rate.

- Very useful simulation modeling technique, and there are some applications that are created in the last few years, including applications that describe real business. At Agent-Based Modeling and Simulator, the system is modeled as a collection of objects that can make inferences each called an agent.

- The advantages of using Agent-Based Modeling and Simulator to model is flexible, describe the real conditions, and provide a way for the evacuation process to be implemented as quickly as possible without any of the victims.

\section{B. Pathfinder}

Pathfinder supports two simulation modes. In Steering mode, agents proceed independently to their goal, while avoiding other occupants and obstacles. Door flow rates are not specified but result from the interaction of occupants with each other and with boundaries. In SFPE mode, agents use behaviors that follow SFPE guidelines, with density-dependent walking speeds and flow limits to doors.[17]

\section{FDS (Fire Dynamics Simulator)}

FDS is a computer program that solves equations that describe the evolution of fire. It is a Fortran program that reads input parameters from a text file, computes a numerical solution to the governing equations, and writes user-specified output data to files. Smoke view is a companion program that reads FDS output files and produces animations on the computer screen. Smoke view has a simple menu-driven interface. However, there are various third-party programs that have been developed to generate the text file containing the input parameters needed by FDS.[4]

FDS can be used in order to create a model some of the following phenomena:

1. The transformation of heat and combustion products at low speeds

2. Transfer of convection and radiation between gas and surface objects

3. Pyrolisys

4. Spread of flame and fire development

5. Detector and Sprinkler Activation

6. Fire Suppression with sprinkle

\section{Pyrosim}

Pyrosim is a graphical user interface for the Fire Dynamics Simulator (FDS). FDS models can predict smoke, temperature, carbon monoxide, and other substances during fires. The results of these simulations have been used to ensure the safety of buildings before construction, evaluate safety options of existing buildings, reconstruct fires for post-accident investigation, and assist in firefighter training. [4]

FDS is a powerful fire simulator, which was developed at the National Institute of Standards and Technology (NIST). FDS simulates fire scenarios using computational fluid dynamics (CFD) optimized for lowspeed, thermally-driven flow. This approach is very flexible and can be applied to fires ranging from stovetops to oil storage tanks. It can also model situations that do not include a fire, such as ventilation in buildings.[11]

\section{E. Performance Standard}

The following performance standards (shown in figure 3), should be complied with calculated evacuation time:

$1.25 \mathrm{R}+\mathrm{T}+2 / 3(\mathrm{E}+\mathrm{L})<\mathrm{n}$

$\mathrm{E}+\mathrm{L}<30^{\prime}$

Calculation of $\mathrm{E}+\mathrm{L}$ should be calculated based on the results of full scale trials on similar ships and evacuation systems or data provided by the manufacturers, however, in this case, the method of calculation should be documented including the value of particular safety factor used. In case neither of the two methods can be used, $\mathrm{E}+\mathrm{L}$ is assumed to be $30 \min [12]$. 
International Journal of Marine Engineering Innovation and Research, Vol. 1(4), Sept. 2017. 295-302 (pISSN: 2541-5972, eISSN: 2548-1479)

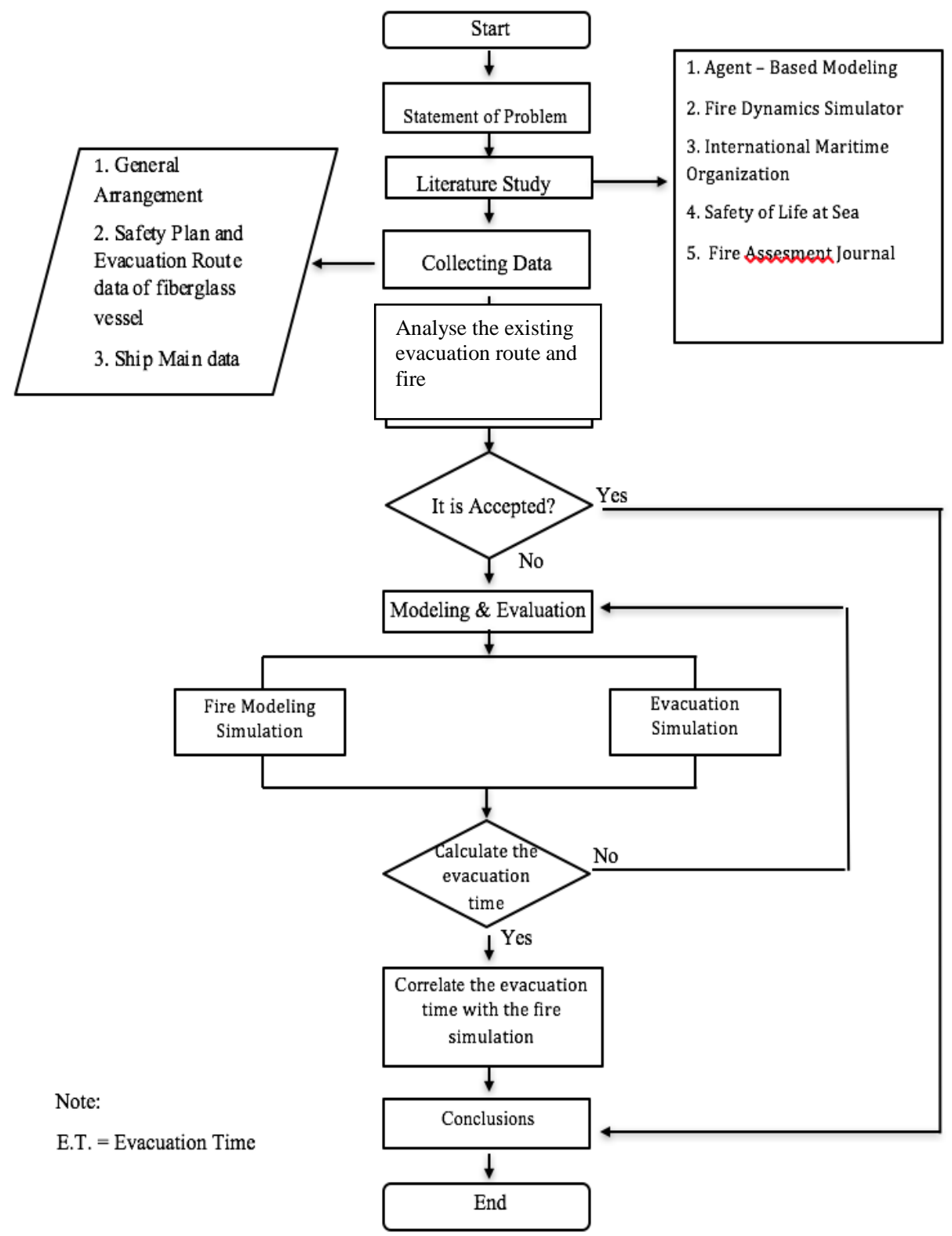

Figure 1. Methoology Flow Chart

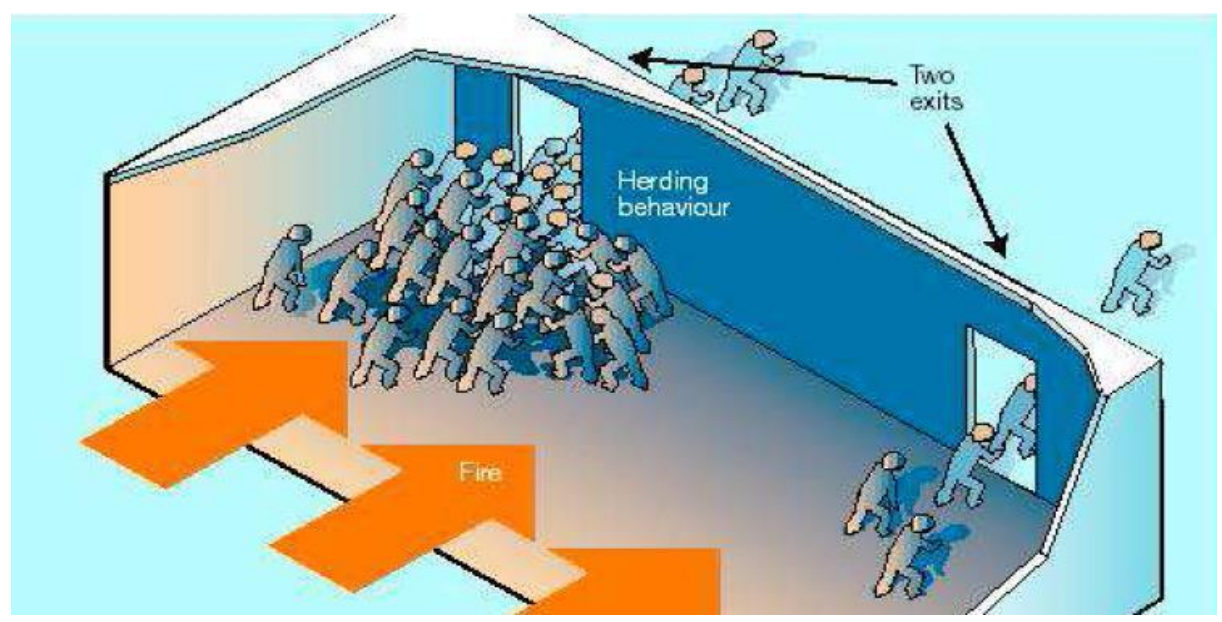

Figure 2. Self - Rescue Efforts [8] 


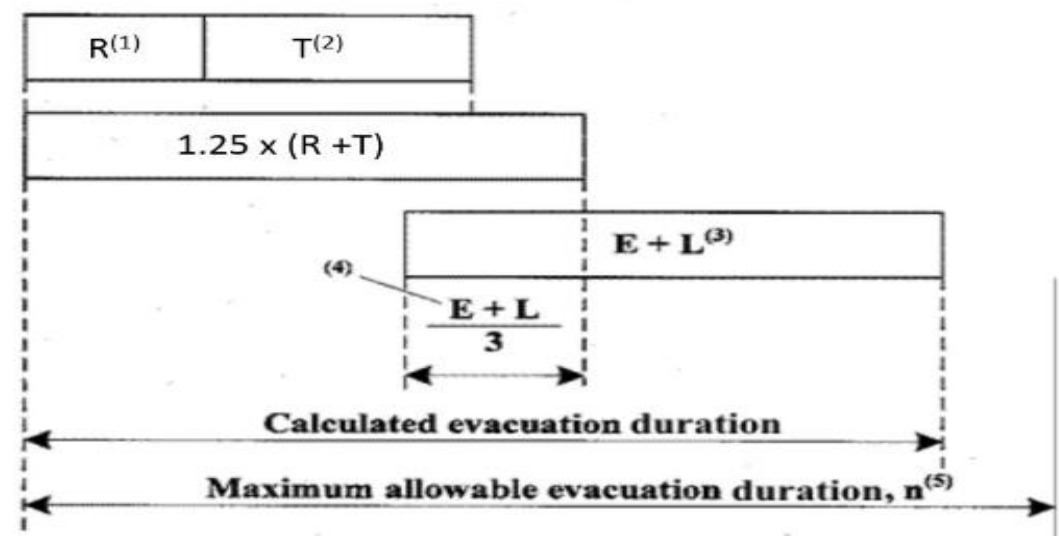

Figure 3. Performance Interim Guidelines[12]

\section{RESULTS AND DISCUSSION}

\section{A. Ship Data}

From the data which has been collected, following are the main data of KM Zahro Express:

$\begin{array}{ll}\text { Name of Ship } & : \text { KM Zahro Express } \\ \text { LoA } & : 26,20 \mathrm{M} \\ \text { Lpp } & : 24,18 \mathrm{M} \\ \text { B } & : 6,00 \mathrm{M} \\ \text { D } & : 1,64 \mathrm{M} \\ \text { GT (Gross Tonnage) } & : 106 \mathrm{GT} \\ \text { NT (Net Tonnage) } & : 32 \mathrm{NT} \\ \text { Material } & : \text { Wood - Fiber Glass } \\ \text { Flag } & : \text { Indonesia } \\ \text { Type } & : \text { Ro-Ro } \\ \text { Year Build } & : 2013\end{array}$

KM Zahro Express is a wooden vessel with a single hull construction is built with traditional methods. Based on the safety certificate of passenger ship, the ship is approved to be able 285 of passengers and 5 persons crew.

KM Zahro Express has 2 decks which are divided into main deck and the upper deck. The decks are the spaces for passenger accommodation with seating facilities (shown in figure 4). Passenger seating located on the main deck and the upper deck materials made of fiber reinforced plastic (FRP). On the topside there is also navigation control room or the Pavilion located at the bow.
KM Zahro Express has the engine room is located at the stern of ship, there are the main engine, engine generators, generator and fuel tank (right side) and the fresh water tank (shown in figure 5). Access to the engine room through the sliding doors in the middle of the back wall of the engine room.

\section{B. Chronology}

KM Zahro Express caught fire at 15 minutes after off-leash (08:30 WIB) at the time of sailing from the port of Muara Angke, Kali Adem to Pulau Tidung. The fire was first seen in the engine room is located on the bottom of the left side of the engine compartment about electric generator ship. The fire burned the ship KM Zahro Express for one hour 26 minutes (at 10.24 WIB ship was pulled to the port of Muara Angke, Kali Adem).

The fire originated from the engine room very quickly propagate to the bow and stern of the ship. Engine room bulkhead that serves as a room divider could not resist fire. These fires resulted in extensive damage throughout the ship's construction, from the deck to the bow section of the aft burnt, building upon the ship, space navigation, engine room and equipment was also destroyed by fire.

Due to a fire accident KM Zahro Express match reports from Basarnas. There are 24 died and 197 people survived (shown in table 1). In accordance with the number of victims was found dead, as many as 20 passengers died found are on the main deck accommodation spaces while the other 4 were found outside the ship.

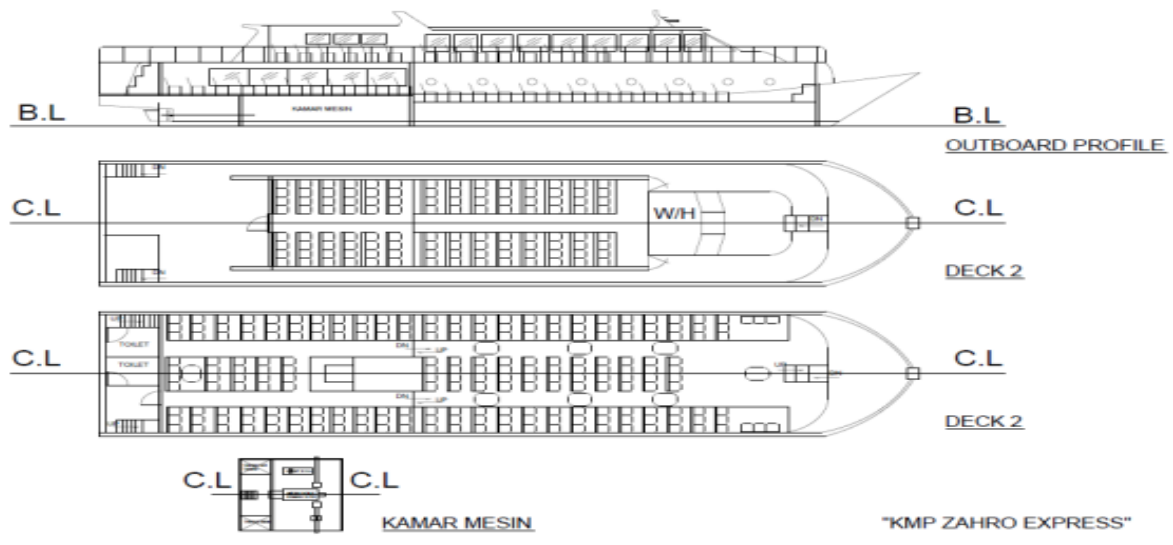




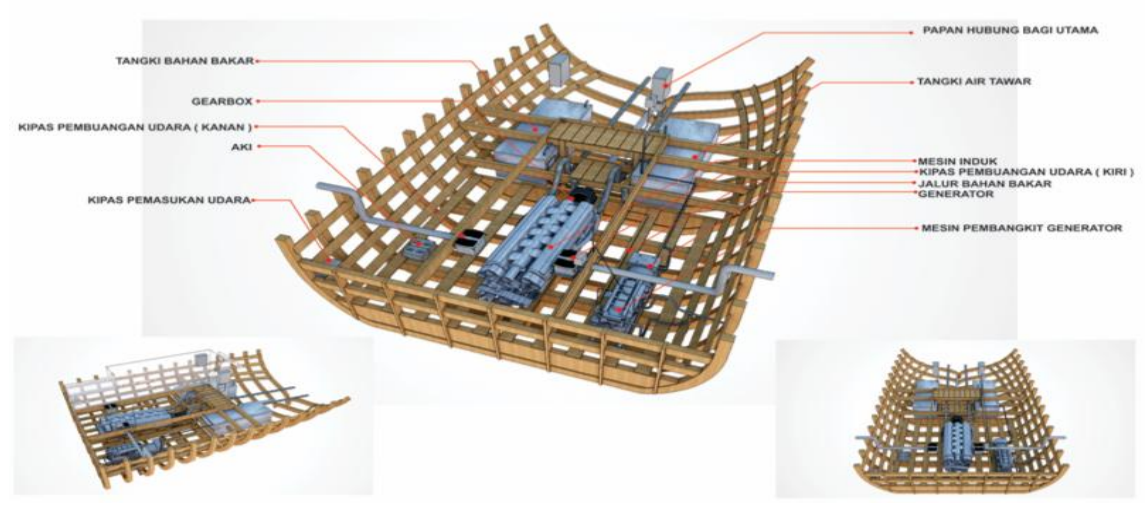

Figure 5. Engine Room Layout of KM Zahro Expess

\section{Creating Simulation Model}

A simulation model can represent the actual of affairs. This simulation model aims to calculate the traveling time on the process of evacuation. The model is created based on the General Arrangement of the KM Zahro Express.

Every room is bounded on all sides by walls. Only one room can occupy the space given, so if one room stacked with another, the overlap will be reduced from the old room and given to a new one. Each room is also equipped with access doors so that passengers can get out of the room toward the evacuation point.

Stairs combining between deck consists of 2 types of staircase, half-landing and straight, the stairs halflanding on deck dominated by passengers, while the stairs straight dominant by crew. The size of stairs is different, according to the volume of people who access the stairs.

After the layout completed, the next step is to add the agent representing passengers and crew. Agent to be added has the characteristics of each.
Height and width of shoulders assuming uniform distribution, altitude agent ranging between $1.58-1.71$ meters for men and $1.47-1.6$ metres for women. While width of shoulder ranging between $34-48$ centimeter for both men and women.

In this simulation process, the most important parameter is the behaviour of agents in the process of evacuation. There are two systems modeling simulation on the Pathfinder software, Steering mode and SFPE mode (shown in figure 6).

Steering mode system attempt to imitation the behaviour and movements of agents. This system depend on the interaction of agents and evasion against the occurrence of collisions between agents.

SFPE system as explained on the SFPE Handbook that controls the flow rate and the queue at the door. evacuation system specified is on the SFPE mode, because congestion arranged so that it does not exceed the initial assumption is $4 \mathrm{p} / \mathrm{m} 2$ for a significant period of time. [14]

TABLE 1.

VICTIMS INFORMATION

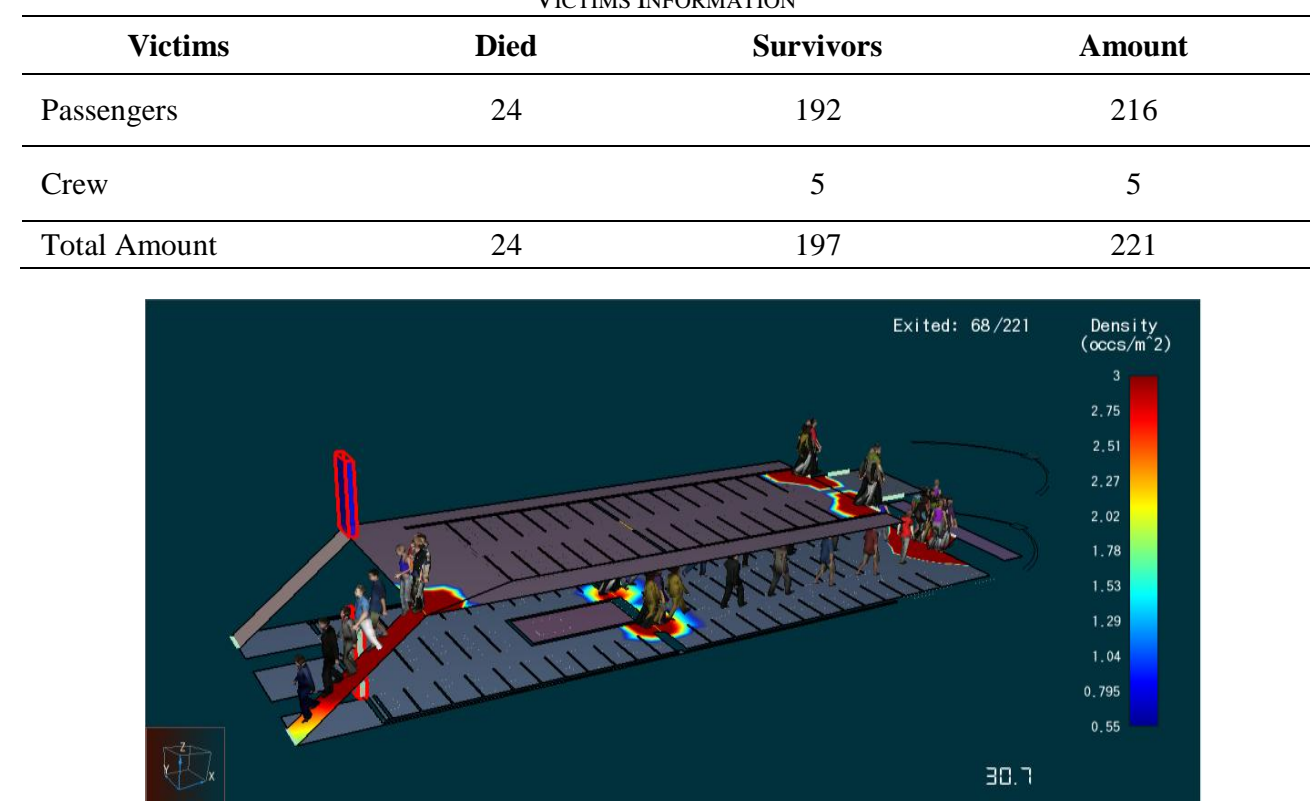




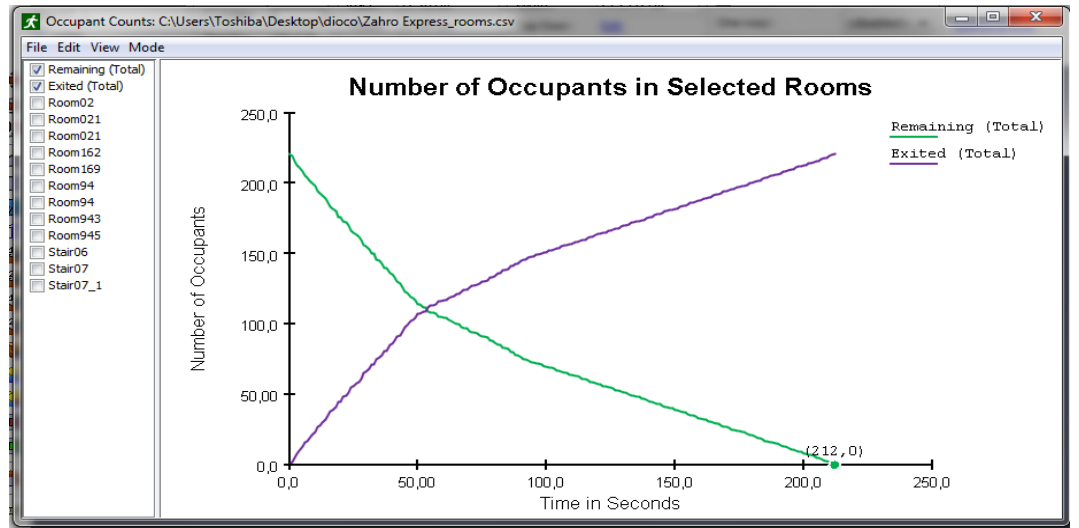

Figure 7. Result of Simulation

On the graph (in figure 7) can be analyzed that the ship KM Zahro Express takes at least 212,0 seconds (travel time) for passengers and crew out of the ship. In this case, the simulation was conducted on the time of day in accordance with the incident.

\section{Result of Evacuation Time Calculation}

After getting the value of traveling time, then the next step is to enter the value of traveling time that has been obtained to the standards of performance.

$1.25 \mathrm{R}+\mathrm{T}+\mathrm{b}(\mathrm{E}+\mathrm{L})<\mathrm{n}$

$(\mathrm{E}+\mathrm{L}) \leq 30$ '

Process simulation of evacuation (traveling time), for this case takes 3,533 minutes (including time delay). Evacuation time calculation as follows:

Evacuation time $=1,25(5)+3,533+2 / 3$ (30) Minute

Evacuation time $=29,783$ Minute

\section{E. Fire Simulation Modeling}

Fire evacuation modeling is modelled to calculate the time of evacuation in case of fire ships. Fire modeling is modelled with an added source of fire and smoke in accordance with material to burn. The burning sources can interfere with the movement of passengers and crew in carrying out the evacuation process. The creating of fire simulation model uses Autocad software, Pathfinder software and Pyrosim software (in table 2).

Creating fire simulation model is started by import a file into autocad to software pyrosim with dimensions of the actual ship and the only room that can be occupied by passengers or crew.

This hole is used for an access point of fire and smoke from one room to another room. The hole can be either a door or stairs connecting each deck.

On the fire simulation model is contained materials used on ships (floor, external wall, and internal wall).
Each type of material has a composition of different materials. Details of the composition of the material is meant to resemble the existing materials on the ship. In addition to sort based on each flash point material fit its characteristics which may allow in the material come into burned by the flame (shown in Table 3 ).

The source of the fire to burn the material added by adding a vent on the location of the source of the fire. Then determine the dimensions according to your needs and provide a profile of the shape functions as a source of fire (burner). After determining the area of the source of the fire, and the value of HRRPA, then specify the source of the fire reaction to fire simulation while it lasted. Using wood reaction, details the composition as follows.[4]

- Carbon atoms 45.0

- Hydrogen Atoms 6.2

- Oxygen Atoms 40.0

- Nitrogen Atoms 0.3

Creation of Mesh on modeling fire serves to limit the fire affected areas in this model. On this restricted mesh modeling is a ship full of open and who are at the top of the ship. Open and functioning for the discharge of smoke or fire resulting in fire modelling so that the smoke from the fires don't get stuck on the limitations of the specified mesh.

Set process simulation modeling of fire in accordance with the desired conditions. The required parameters in the simulation is run time restrictions in running a simulation of a fire. Time used 1800 seconds. This time refers to the process of traveling time cases previously which takes no more than 1800 seconds. 


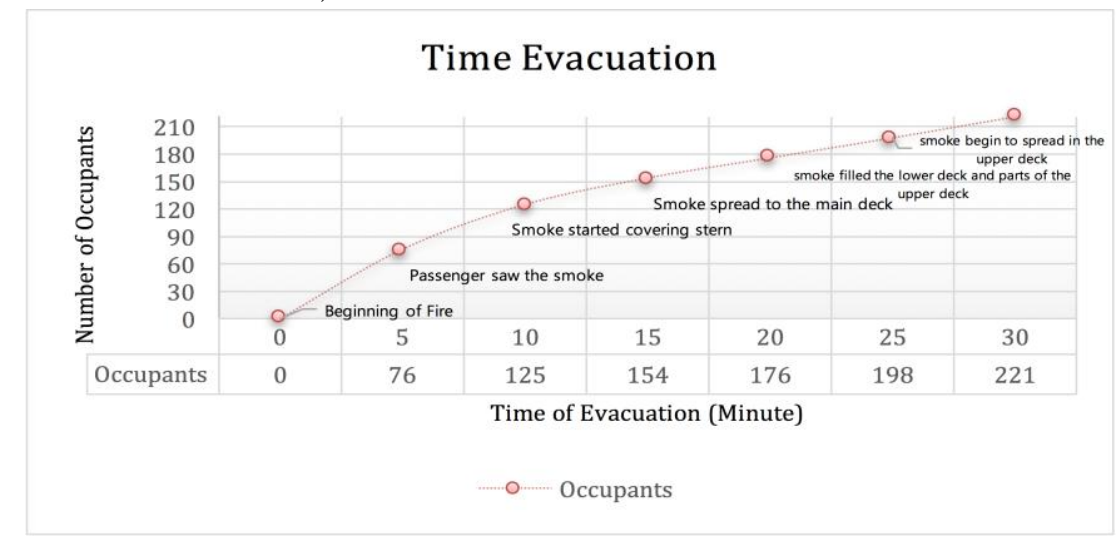

Figure 8. Relation between Evacuation Time and Fire Simulation

\section{F. Result of Fire Simulation Model}

Results from simulations of fires is a graphic animations of the simulation, in addition also produces graphs of parameter that is already installed (in figure 7). Animated graphics also produce planar graphs that have been installed (slices).

Any other results that can be used to identify environmental is a graph from the results of installation the device. This is very important because of the graph can be seen the temperature specific heat, as well as a percentage of the amount of smoke that how around the device installed.

The analysis has been done conclude some points as follows:

1. Process simulation is done for 1800 seconds do not produce a large fire, only produces smoke that allows agents to carry out performance disrupts the process of evacuation simulation

2. The results of this simulation produces smoke that reaches throughout the body of the ship because of the location of the access stairs connecting enter deck is at near the source of the fire.

\section{G. Analysis of Fire Simulation Modeling}

Modelling of fire have resulted can be integrated with external evacuation modeling. It can be easier to analyze the impact that resulted in a change of the evacuation time on a variation of such cases.

The occurrence of gradations on walking speed each agent can be affected by smoke and temperature. White smoke is highly irritating to the eye produced by burning wood cribs, black smoke is less irritant produced by burning kerosene. To limit the visible sign of a run, the following relationship can be presented in Cs. Walking speed is constant, but for the visibility of the Agency declined. Visibility or ability seen in smoke irritate dropped sharply on the smoke density exceeds a certain level. In smoke irritate with thick concentration, the eyes can not open for a long time and couldn't see the words on the signs of the evacuation.

Even in this case, when the signs are so simple or familiar with the passengers or crew to be understood at a glance, the effect of irritating fumes may not cause problems to identify. Irritant smoke reduces visibility of the Agency, especially when there is the possibility for panic.[1]

On this figure 8 , this chart shows number of occupants that can evacuated in the beginning of smoke caused by fire. In the beginning of fire, none of passenger notice the fire.

TABLE 2.

The Process of CREATING A FIRE SiMUlation MOdEL

\begin{tabular}{cccc}
\hline Software & Autocad & Pathfinder & Pyrosim \\
\hline Function & $\begin{array}{c}\text { Create ship design on each } \\
\text { deck of the ship }\end{array}$ & $\begin{array}{c}\text { Create the evacuation } \\
\text { modeling }\end{array}$ & Create the fire modeling \\
Description & $\begin{array}{c}\text { Model based on the General } \\
\text { Plan of the ship KMP. Zahroo } \\
\text { Express }\end{array}$ & $\begin{array}{c}\text { Produce a traveling time } \\
\text { is later processed into } \\
\text { the total process of } \\
\text { evacuation time }\end{array}$ & $\begin{array}{c}\text { Create fire modeling from } \\
\text { layouts drawn on Autocad }\end{array}$ \\
\hline
\end{tabular}


International Journal of Marine Engineering Innovation and Research, Vol. 1(4), Sept. 2017. 295-302

TABLE 3.

MATERIAL ON FirE SiMULATION MODEL

\begin{tabular}{cccc}
\hline Material & Floor & External Wall & Internall Wall \\
\hline Description & The material used as the floor & $\begin{array}{c}\text { The material used on } \\
\text { the external walls of the } \\
\text { ship }\end{array}$ & $\begin{array}{c}\text { The material used on the } \\
\text { internal walls of the ship parts } \\
\text { in separating room }\end{array}$ \\
\hline Composition & Mentu Wood & $\begin{array}{c}\text { Mentu Wood and Fiber } \\
\text { Glass }\end{array}$ & Mentu Wood and Fiber Glass \\
\hline
\end{tabular}

\section{CONCLUSION}

1. Characteristics of the ship's passengers and crew the associated walking speed in each case is different. Walking speed reduction occurs when accidents or fires that affect the length of the evacuation process.

2. Evacuation simulation calculation result in normal condition is 29.783 minutes, the simulation is done during the day and according to the actual conditions, in these simulation there were 216 passengers and 5 crews, who can be evacuated. It seems that the unsucces of passenger evacuation is not due to the mistaken of evacuation route.

3. There were 24 passengers (20 People died cause fire and 4 People were found in the sea) who died on the case because of the panic and not ready to accept the situation of emergency.

\section{REFERENCES}

[1] Komite Nasional Keselamatan Transportasi \& PT. Trans Asia Consultants, "Kajian Analisis Trend Kecelakaan Transportasi Laut Tahun 2003 - 2008," p. 79, 2009.

[2] S. Umaiyah, "Analisa Penyebab Kebakaran pada Kapal - Kapal Penyeberangan Jarak Pendek dan Usulan Peningkatan Sistem Manajemen Keselamatannya," Program Studi Teknik Perkapalan, Departemen Teknik Mesin, Fakultas Teknik, Universitas Indonesia, Depok 16424, 2015.

[3] C. M. Macal and M. J. North, "Agent-Based Modeling and Simulation," pp. 86-98, 2009.

[4] K. McGrattan, R. McDermott and C. Weinschenk, "Fire Dynamics Simulator User's Guide," vol. 6, 2013.

[5] International Maritime Organization, "Guidelines for Evacuation Analysis for New and Existing Passanger Ships," 2007.

[6] "Materi Prosedur Keadaan Darurat dan SAR Search and Rescue," August 2011. [Online]. [Accessed December 2016].

[7] S. Bandini, S. Manzoni and G. Vizzari, "Agent-Based Modeling and Simulation: An Informatic Perspective," 31 October 2009.

[8] P. P. Razafinjatovo, "Shipboard emergency response plan at sea," 1999.

[9] L. Valasek, "The use of PyroSim graphical user interface for FDS simulation of a cinema fire," vol. 7, 2013.

[10] Komite Nasional Keselamatan Transportasi, "Data Investigasi Kecelakaan Pelayaran Tahun 2010 - 2016," 25 November 2016.

[11] Thunderhead Engineering, Pyrosim User Manual, thunderhead engineering, 2015.

[12] International Maitime Organization, "Guidelines For Evacuation Analysis For New And Existing Passenger Ships," in MSC.1/Circ.1238, 2016.
[13] L. Valasek, G. J and W. P, "Use of PyroSim for Simulation of Cinema Fire," vol. 7, March 2012.

[14] F. W. Mowrer and H. E. Nelson, Fire Protection Engineering, vol. 19, National Fire Protection Association, 2003.

[15] International Maritime Organization, "Interim Guidelines for a Simplified Evacuation Analysis on RO-RO Passenger Ships," vol. MSC/Circ.909, 1999.

[16] T. Jin, "Studies On Human Behavior And Tenability In Fire Smoke," 1997.

[17] T. Engineering, Pathfinder User Manual, Manhattan Thunderhead Engineering, 2017.

[18] Zaman M B, Priyanta D, Afrianza I. "Evacuation Analysis of 1200 GT Passenger Ship in Case of Fire using Agent-Based Modeling Approach." International Journal of Marine Engineering Innovation and Research., vol. 1, no. 1, Dec. 2016. 